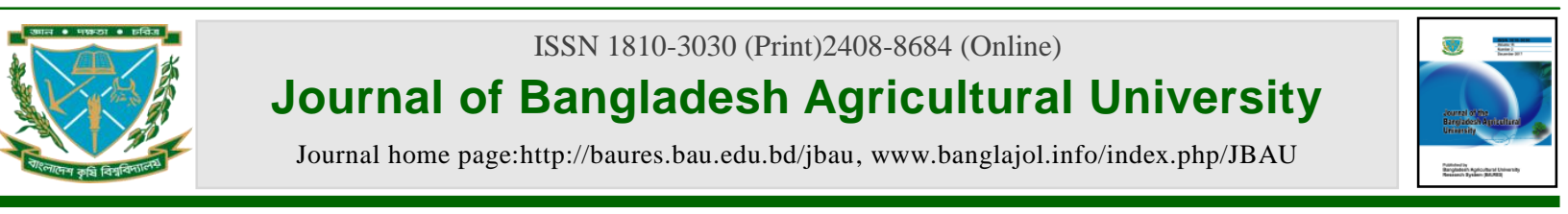

\title{
Light and temperature effects on sprout yield and its proximate composition and vitamin $C$ content in Lignosus and Mung beans
}

\author{
MJ Islam, MK Hassan ${ }^{1}$, SR Sarker ${ }^{2}$, AB Rahman ${ }^{3}$ and MSA Fakir \\ Department of Crop Botany, Bangladesh Agricultural University, Mymensingh, Bangladesh. \\ ${ }^{1}$ Department of Horticulture, ${ }^{2}$ Department of Seed Science and Technology, ${ }^{3}$ Department of Genetics and Plant Breeding, \\ Bangladesh Agricultural University, Mymensingh
}

\section{ARTICLE INFO}

Article history:

Received: 02 November 2017

Accepted: 22 December 2017

Keywords:

Bean sprouts, nutrients, light, temperature

Correspondence:

MSA Fakir

(fakirmsa@gmail.com)

\begin{abstract}
Bean sprout is used as vegetables. The present study investigated the effect of temperature and light on seed germination and sprout yield, and proximate (crude protein, crude fat, crude fibre, nitrogen free extract and ash) composition of sprout in Lignosus (Dipogon lignosus (L.) Verdc.) and Mung (Vigna radiata Wilczek) beans. Three temperatures (ambient, $25^{\circ}$ and $30^{\circ} \mathrm{C}$ ) and two light regimes; continuous dark, (CD) and continuous dark alternated by $1 / 2$ hour light daily, (DAL) were used for seed germination and bean sprout yield. Data were collected 24, 48, 72, 96 and 120 hours after setting the presoaked seeds in the petri dishes. Of the temperature regimes, generally better seed germination and sprout fresh weight (yield) were observed at $25^{\circ} \mathrm{C}$ in Mung bean and $30^{\circ} \mathrm{C}$ in Lignosus bean. Germination and sprout yield were similar under CD and DAL. Both under CD and DAL, sprout yield was higher after 120 hours compared to $96 \mathrm{hrs}$ after germination in both the beans. Proximate composition of dry seeds and their sprouts was also determined. Irrespective of species, crude protein content was significantly higher in sprout (average of $29.33 \%$ ) than dry seed (average of 24.33\%).Vitamin C was significantly higher in

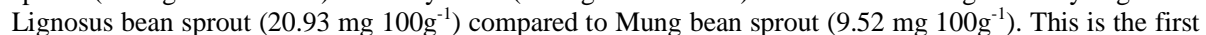
world report on Lignosus bean sprout. It may be concluded that better sprout yield and good protein content were obtained at $25^{\circ} \mathrm{C}$ in Mung bean and $30^{\circ} \mathrm{C}$ in Lignosus bean after $120 \mathrm{hrs}$ of germination irrespective of dark and light.
\end{abstract}

\section{Introduction}

Both Lignososus (Dipogon lignosus (L.) Verdc.) and Mung (Vigna radiate Wilczek) beans are members of Fabaceae. In developing countries including Bangladesh, most of the proteins consumed come from plant sources and this is cheaper than proteins from animal sources (mainly fish and meat) (Rashid, 1999). Bean sprouts are one of the most complete, nutritious, predigested foods with higher biological efficiency and lower levels of anti-physiologic factors than raw or cooked seeds (Balasaraswathi and Sadasivum, 1997; Yang et al. 2001; Kaur and Kawarta, 2002). Mung bean sprouts are used in many food items including breakfast, salads, soups, casseroles, pasta and baked products. Nutritionists advocate the use of bean sprout as both vegetable and meat. Bean sprouts are used fresh and cooked and are sources of proteins, amino acids, hormones, enzymes, vitamin $\mathrm{C}$, antioxidants, minerals and other chemicals of health benefit (Chen et al. 1987; Yang et al. 2001; Venyl et al. 2009; Surani and Rauf, 2010; Chen et al. 2012; Meyerowitz, 2012). Further, foods containing both bean sprout and rice provide better nutrition since sprout contains certain amino acids while rice contain different amino acids.

Germination improves nutritional and functional properties in cowpea (Giami, 1993), sorghum (Abbas et al. 2008) and wheat (Hussain and Uddin, 2012).
Sprouting has been identified as an inexpensive but effective technology for improvements of nutrition and quality of cereals and grain legumes and is associated with improvement of nutritive value of seeds (Zanabria et al. 2006; Khattak et al. 2007). Proteins break down into amino acids and water-soluble vitamins such as Bcomplex and vitamin C. At the same time there are reports that germination is effective in reducing phytic acid, flatulence causing oligosaccharides and polyphenols thereby increasing protein digestibility and improving sensory properties (Lintschinger et al. 1997; Zanabria et al. 2006; Khattak et al. 2007). Recently, it has been reported that germination under different type of illumination has significant effect on biosynthesis of ascorbic acid and sprout yield of soybean and chickpea (Mao et al. 2005; Khattak et al. 2007). Most researchers used Mung bean and chickpea seeds for sprout production and its chemical composition but such investigation is lacking in Lignosus bean in the world. Although information on pod and seed growth is available (Fakir et al. 2008, 2009; Fakir and Hassan, 2009) there is only one report on sprout yield and quality in Lignosus bean in world literature (Islam, 2010).

Dormant seeds are essentially storehouses of reserve food; their synthetic powers being released only on being germination under favorable moisture and temperature. Selection of species/varieties suitable for 
sprouting and good nutrients is important. Likewise, environmental factors hasten germination viz., keeping seeds in dark or continuous dark alternated by light and different temperatures needs investigation. Biological tests also need to be made to detect any alteration in the nutritional/proximate composition as a result of sprouting. Shah et al. (2011) reported that sprouting resulted in increase in crude protein and crude fiber but decrease in nitrogen free extract and ash in Mung bean. Such research is lacking in Lignosus bean. Although scanty information of the effect of light and temperature requirements for suitable bean sprouts production is available in Mung bean in Bangladesh, there is no published information on Lignosus bean sprout production and its nutritional composition in the world literature. The present research investigated the effect of (i) temperature and light requirement on sprout yield; and (ii) proximate composition of dry seed and sprout in Lignosus and Mung beans.

\section{Materials and Methods}

The experiment was carried out at the laboratories of the Department of Crop Botany, Horticulture and Animal Nutrition, Bangladesh Agricultural University, Mymensingh during the period from March to November 2009.

Atmospheric conditions of the storage room: Temperature and relative humidity of the storage room were recorded daily. The averages of the minimum and maximum temperatures of the storage room were 23.7 and $31.82^{\circ} \mathrm{C}$, respectively (average $27.76^{\circ} \mathrm{C}$ ) and relative humidity ranged from 75.15 to $87.48 \%$.

Experimental materials: Mature dry seeds of Lignosus and Mung beans were used as experimental materials. The Lignosus bean (Trinidad genotype) seeds were collected from previous experiment in Crop Botany Department, Bangladesh Agricultural University, Mymensingh and Mung bean (BINA moog-6) seeds were collected from the Physiology Division, Bangladesh Institute of Nuclear Agriculture, Mymensingh.

Seed preparation: The seeds were tested for imbibition to observe maximum water absorbing capacity. Ten seeds were placed in each petri dish in distilled water soaked tissue in quadruplicates. Weight of seeds was recorded at every 4, 8, 12 and 16 hours after setting the test. From that data, weight increased due to imbibition was calculated by subtracting primary seed weight from final weight. From the test it was found that the maximum water absorption occurred 12 hours after imbibition period in both the species. For actual experiments, seeds were subsequently soaked for 12 hours before starting of the main experiments.
Procedure: For successful sprout preparation, clean and uniform seeds were sorted following soaking in water for twelve hours. The seeds were rinsed with about 500 $\mathrm{ml}$ of water containing approximately one gram of calcium hypochlorite (bleaching powder) before soaking. After soaking, seeds were placed in petri dishes containing moistened tissue at the bottom. The petri dishes were kept at ambient temperature (minimum, 23.7 to maximum, $31.82^{\circ} \mathrm{C}$; mean $27.76^{\circ} \mathrm{C}$ ) or in the germinator maintaining at $25^{\circ}$ or $30^{\circ} \mathrm{C}$ ) for germination. The seeds were rinsed everyday with bleaching powder solution. To observe the effect of light on sprouting, the selected petri dishes were kept in the light for half an hour daily basis. Otherwise the petri dishes were kept in dark condition in the germinator. Five (two each on Mung and Lignosus beans, and fifth on nutritional composition), experiments were carried out. Firstly, Two factors (temperature and sprout harvesting time) experiments were conducted in randomized complete design for investigating the effect of temperature and time of harvest on seed germination and sprout production in Lignosus bean and Mung bean in separate setup. The three temperatures were ambient, 25 and $30^{\circ} \mathrm{C}$ and five harvesting times were $24,48,72,96$ and 120 hours after setting the germination test.There were $15(5 \times 3)$ treatments with four replications. The standard germination procedure was followed according to ISTA rules. The whole experiment was set under continuous dark condition in the germinator (Refrigerated incubator FOC 2251, VELP Scientifica). To investigate the effect of light and time of harvest on seed germination and sprout yield in Lignosus and Mungbean, two factors (light regimes and sprout harvest time) experimental setup was conducted at ambient temperature. Two light regimes were continuous dark (CD) and continuous dark alternated by $1 / 2$ hour light daily (DAL), and five harvesting times were 24, 48, 72, 96 and 120 hours after setting the germination test. The $10(2 \times 5)$ treatments were arranged in CRD with four replications. The standard germination procedure was followed. Proximate composition (crude protein, crude fat, crude fibre, nitrogen free extract and ash) of seeds and sprout of Mung and Lignosus beans were determined (AOAC, 2005). Vitamin C (ascorbic acid) was assayed in fresh bean sprouts at 5-day and 3-day old seedlings of Lignosus and Mung beans, respectively following the method of Agustin et al. (1985). The concentration was expressed as milligram of vitamin $\mathrm{C} 100 \mathrm{~g}^{-1}$ of the fresh sprout.

Data collection and analysis: Data on \% germination; seed weight; total dry matter of seed; sprout fresh weight (yield); total dry matter of sprout; stem length etc. were recorded. The means were compared by Duncan Multiple Range test (Gomez and Gomez, 1984). 


\section{Results and Discussion}

Temperature effect on seed germination and sprout yield in Lignosus bean: Temperature influenced seed germination, sprout length, and sprout fresh and dry weights $(\mathrm{P} \leq 0.05)$ (Table 1$)$. Generally, germination, sprout length, sprout fresh and dry weights increased with increasing duration (Table 1). Germination was found better between 48 and 120 hours duration. The higher sprout length was noted 120 hours after setting the presoaked seeds while the sprout dry weight was found better between 96 and 120 hours after setting the seeds. However, the maximum fresh weight was observed 120 hours setting the test. The interaction of temperature and duration on seed germination, sprout length and sprout fresh weight were observed significant $(\mathrm{P} \leq 0.05)$ (Table 1). The germination was increased by 6-folds between 24 and 120 hours at ambient temperature and the figures were 4.5 -folds both at 25 and $30^{\circ} \mathrm{C}$. On the other hand, sprout length was increased by 67.5 folds between 24 and 120 hours at ambient temperature and the figures were 14 and 40 times at 25 and $30^{\circ} \mathrm{C}$, respectively. Sprout yield (sprout fresh weight) was increased with increasing duration at all temperature ranges, the magnitude being much greater between 24 and 120 hours at $30^{\circ} \mathrm{C}$ (2.42 folds) than at $25^{\circ} \mathrm{C}$ (2.03 folds) and ambient (1.73 folds). However, sprout dry weight was greater at 120 hours at all temperatures.

\section{Temperature effect on seed germination and sprout yield in Mung bean:}

Generally, sprout length and weight increased with increasing duration (Table 2). Sprout length and fresh weights were highest between 96 and 120 hours. However, sprout dry weights were highest between 24 and 48 hours after setting the test. The interaction of temperature and duration on sprout length and sprout fresh and dry weights were significant (Table 2). Sprout length increased by 8 -folds between 24 and 120 hours at ambient temperature, 9-folds at $25^{\circ} \mathrm{C}$ and 13 -folds at $30^{\circ} \mathrm{C}$. On the other hand sprout fresh weight increased by 4 times between 24 and 120 hours at ambient temperature and the figures were 4.7 -folds and 1.7 -folds at 25 and $30^{\circ} \mathrm{C}$, respectively.

Table 1: Combined effect of temperature and harvest duration on seed germination and sprout yield attributes in Lignosus bean

\begin{tabular}{lllllll}
\hline $\begin{array}{l}\text { Temperature } \\
(\mathbf{C})\end{array}$ & $\begin{array}{l}\text { Harvest } \\
\text { duration } \\
\text { (hrs) }\end{array}$ & $\begin{array}{l}\text { Sun dry } \\
\text { Seed wt./10- } \\
\text { seeds (g) }\end{array}$ & $\begin{array}{l}\text { Germi- } \\
\text { nation } \\
(\mathbf{\%})\end{array}$ & $\begin{array}{l}\text { Sprout } \\
\text { length (cm) }\end{array}$ & $\begin{array}{l}\text { Sprout fresh } \\
\text { wt/10-Seed } \\
\text { ling (g) }\end{array}$ & $\begin{array}{l}\text { Sprout } \\
\text { dry wt. /10- } \\
\text { seedlings (g) }\end{array}$ \\
\hline Ambient & 24 & $3.17 \mathrm{e}$ & $10.0 \mathrm{~b}$ & $0.09 \mathrm{e}$ & $4.91 \mathrm{~g}$ & $2.75 \mathrm{fg}$ \\
& 48 & $3.24 \mathrm{cde}$ & $65.0 \mathrm{a}$ & $1.33 \mathrm{~d}$ & $6.36 \mathrm{f}$ & $2.80 \mathrm{defg}$ \\
& 72 & $3.23 \mathrm{cde}$ & $72.5 \mathrm{a}$ & $2.57 \mathrm{c}$ & $7.13 \mathrm{de}$ & $2.9 \mathrm{bcdef}$ \\
& 96 & $3.19 \mathrm{de}$ & $67.5 \mathrm{a}$ & $3.88 \mathrm{~b}$ & $7.64 \mathrm{~cd}$ & $2.92 \mathrm{bcd}$ \\
& 120 & $3.21 \mathrm{de}$ & $62.5 \mathrm{a}$ & $6.07 \mathrm{a}$ & $8.49 \mathrm{~b}$ & $3.01 \mathrm{ab}$ \\
& 24 & $3.51 \mathrm{ab}$ & $15.0 \mathrm{~b}$ & $0.40 \mathrm{e}$ & $4.28 \mathrm{hi}$ & $2.69 \mathrm{gh}$ \\
& 48 & $3.46 \mathrm{abc}$ & $72.5 \mathrm{a}$ & $1.39 \mathrm{~d}$ & $6.18 \mathrm{f}$ & $2.77 \mathrm{efg}$ \\
& 72 & $3.41 \mathrm{abcd}$ & $72.5 \mathrm{a}$ & $2.43 \mathrm{c}$ & $7.41 \mathrm{cde}$ & $2.87 \mathrm{cdef}$ \\
& 96 & $3.56 \mathrm{a}$ & $65.0 \mathrm{a}$ & $3.88 \mathrm{~b}$ & $7.23 \mathrm{cde}$ & $2.89 \mathrm{bcde}$ \\
& 120 & $3.62 \mathrm{a}$ & $67.5 \mathrm{a}$ & $5.78 \mathrm{a}$ & $8.74 \mathrm{~b}$ & $2.96 \mathrm{abc}$ \\
& 24 & $3.32 \mathrm{bcde}$ & $15.0 \mathrm{~b}$ & $0.15 \mathrm{e}$ & $4.05 \mathrm{i}$ & $2.42 \mathrm{i}$ \\
& 48 & $3.27 \mathrm{cde}$ & $65.0 \mathrm{a}$ & $1.43 \mathrm{~d}$ & $4.83 \mathrm{gh}$ & $2.59 \mathrm{~g}$ \\
& 72 & $3.42 \mathrm{abcd}$ & $60.0 \mathrm{a}$ & $2.43 \mathrm{c}$ & $6.98 \mathrm{e}$ & $2.69 \mathrm{gh}$ \\
& 96 & $3.23 \mathrm{de}$ & $57.5 \mathrm{a}$ & $3.95 \mathrm{~b}$ & $7.84 \mathrm{c}$ & $2.95 \mathrm{abc}$ \\
\hline
\end{tabular}

In a column under a particular variable, figures followed by different letter (s) are significant at $\mathrm{P} \leq 0.05$ 
Table 2. Combined effect of temperature and harvest duration on seed germination and Sprout yield attributes in Mung bean

\begin{tabular}{lllllll}
\hline $\begin{array}{l}\text { Tempera- } \\
\text { ture (C) }\end{array}$ & $\begin{array}{l}\text { Harvesting } \\
\text { duration } \\
(\mathbf{h r s})\end{array}$ & $\begin{array}{l}\text { Sun dry } \\
\text { Seed wt. / } \\
\text { 10-seeds }(\mathbf{g})\end{array}$ & $\begin{array}{l}\text { Germination } \\
(\boldsymbol{\%})\end{array}$ & $\begin{array}{l}\text { Sprout } \\
\text { length }(\mathbf{c m})\end{array}$ & $\begin{array}{l}\text { Sprout fresh } \\
\text { wt/10- } \\
\text { seedlings(g) }\end{array}$ & $\begin{array}{l}\text { Sprout dry } \\
\text { wt. /10 - } \\
\text { seedlings (g) }\end{array}$ \\
\hline Ambient & 24 & $0.63 \mathrm{ab}$ & $98.0 \mathrm{a}$ & $3.310 \mathrm{gh}$ & $1.28 \mathrm{fg}$ & $0.46 \mathrm{bc}$ \\
& 48 & $0.60 \mathrm{abcd}$ & $95.0 \mathrm{a}$ & $6.225 \mathrm{fg}$ & $1.98 \mathrm{ef}$ & $0.42 \mathrm{bcdef}$ \\
& 72 & $0.64 \mathrm{a}$ & $97.5 \mathrm{a}$ & $15.71 \mathrm{~d}$ & $3.98 \mathrm{c}$ & $0.42 \mathrm{bcdef}$ \\
& 96 & $0.64 \mathrm{a}$ & $90.0 \mathrm{a}$ & $23.06 \mathrm{bc}$ & $4.72 \mathrm{ab}$ & $0.38 \mathrm{f}$ \\
& 120 & $0.61 \mathrm{abc}$ & $99.0 \mathrm{a}$ & $26.15 \mathrm{a}$ & $4.98 \mathrm{a}$ & $0.41 \mathrm{cdef}$ \\
& 24 & $0.58 \mathrm{cdef}$ & $95.0 \mathrm{a}$ & $2.793 \mathrm{~h}$ & $1.13 \mathrm{~g}$ & $0.44 \mathrm{bcde}$ \\
& 48 & $0.59 \mathrm{abcde}$ & $97.5 \mathrm{a}$ & $5.993 \mathrm{fg}$ & $1.93 \mathrm{ef}$ & $0.41 \mathrm{bcdef}$ \\
& 72 & $0.56 \mathrm{def}$ & $92.5 \mathrm{a}$ & $12.68 \mathrm{e}$ & $3.96 \mathrm{c}$ & $0.39 \mathrm{ef}$ \\
& 96 & $0.54 \mathrm{ef}$ & $100.0 \mathrm{a}$ & $20.70 \mathrm{c}$ & $4.85 \mathrm{a}$ & $0.41 \mathrm{def}$ \\
& 120 & $0.53 \mathrm{f}$ & $100.0 \mathrm{a}$ & $25.02 \mathrm{ab}$ & $5.26 \mathrm{a}$ & $0.42 \mathrm{bcdef}$ \\
& 24 & $0.56 \mathrm{cdef}$ & $97.5 \mathrm{a}$ & $1.740 \mathrm{~h}$ & $2.45 \mathrm{de}$ & $0.53 \mathrm{a}$ \\
& 48 & $0.58 \mathrm{cdef}$ & $95.0 \mathrm{a}$ & $7.075 \mathrm{f}$ & $2.48 \mathrm{de}$ & $0.47 \mathrm{~b}$ \\
& 72 & $0.59 \mathrm{bcdef}$ & $90.0 \mathrm{a}$ & $11.09 \mathrm{e}$ & $2.93 \mathrm{~d}$ & $0.45 \mathrm{bcd}$ \\
& 96 & $0.58 \mathrm{cdef}$ & $90.0 \mathrm{a}$ & $23.54 \mathrm{abc}$ & $3.98 \mathrm{c}$ & $0.40 \mathrm{def}$ \\
& 120 & $0.58 \mathrm{bcdef}$ & $97.5 \mathrm{a}$ & $22.55 \mathrm{bc}$ & $4.14 \mathrm{bc}$ & $0.41 \mathrm{cdef}$ \\
\hline
\end{tabular}

In a column under a particular variable, figures followed by different letter (s) are significant at $\mathrm{P} \leq 0.05$

Table 3. Combined effect of Light and Harvest duration on seed germination and sprout yield parameters in Lignosus Bean

\begin{tabular}{lllllll}
\hline CD/ DAL & $\begin{array}{l}\text { Harvest } \\
\text { duration } \\
\text { (hours) }\end{array}$ & $\begin{array}{l}\text { Sun dry } \\
\text { Seed wt./ } \\
\text { 10-seeds }(\mathbf{g})\end{array}$ & $\begin{array}{l}\text { Germi- } \\
\text { nation } \\
(\%)\end{array}$ & $\begin{array}{l}\text { Sprout } \\
\text { length }(\mathbf{c m})\end{array}$ & $\begin{array}{l}\text { Sprout fresh } \\
\text { wt/10- } \\
\text { seedlings }(\mathbf{g})\end{array}$ & $\begin{array}{l}\text { Sprout dry } \\
\text { wt./10- } \\
\text { seedlings } \\
(\mathbf{g})\end{array}$ \\
\hline $\mathrm{CD}$ & 24 & $3.17 \mathrm{c}$ & $10.0 \mathrm{~b}$ & $0.09 \mathrm{e}$ & $4.90 \mathrm{~d}$ & $2.75 \mathrm{cde}$ \\
& 48 & $3.23 \mathrm{bc}$ & $65.0 \mathrm{a}$ & $1.32 \mathrm{~d}$ & $6.36 \mathrm{c}$ & $2.79 \mathrm{bcde}$ \\
& 72 & $3.23 \mathrm{bc}$ & $72.5 \mathrm{a}$ & $2.56 \mathrm{c}$ & $7.12 \mathrm{~b}$ & $2.88 \mathrm{abc}$ \\
& 96 & $3.19 \mathrm{c}$ & $67.5 \mathrm{a}$ & $3.87 \mathrm{~b}$ & $7.64 \mathrm{~b}$ & $2.92 \mathrm{ab}$ \\
& 120 & $3.21 \mathrm{bc}$ & $62.5 \mathrm{a}$ & $6.07 \mathrm{a}$ & $8.49 \mathrm{a}$ & $3.01 \mathrm{a}$ \\
& 24 & $3.50 \mathrm{a}$ & $17.5 \mathrm{~b}$ & $0.44 \mathrm{e}$ & $4.25 \mathrm{e}$ & $2.69 \mathrm{e}$ \\
& 48 & $3.45 \mathrm{ab}$ & $72.5 \mathrm{a}$ & $1.41 \mathrm{~d}$ & $6.18 \mathrm{c}$ & $2.73 \mathrm{de}$ \\
& 72 & $3.40 \mathrm{abc}$ & $72.5 \mathrm{a}$ & $2.75 \mathrm{c}$ & $7.45 \mathrm{~b}$ & $2.87 \mathrm{abc}$ \\
& 96 & $3.56 \mathrm{a}$ & $67.5 \mathrm{a}$ & $3.86 \mathrm{~b}$ & $7.74 \mathrm{~b}$ & $2.87 \mathrm{abcd}$ \\
& 120 & $3.61 \mathrm{a}$ & $70.0 \mathrm{a}$ & $5.77 \mathrm{a}$ & $8.77 \mathrm{a}$ & $3.01 \mathrm{a}$ \\
\hline
\end{tabular}

In a column under a particular variable, figures followed by different letter (s) are significant at $\mathrm{P} \leq 0.05$

CD: Continuous dark, and DAL: Dark alternated Light

Effect of Light on seed germination and sprout production in Mung bean:

Two light conditions i.e. continuous dark (CD) and continuous dark alternated by $1 / 2$ hour light daily (DAL) had significant effect on sprout length and fresh weight
$(\mathrm{P} \leq 0.05)$ (Table 4). Both sprout length and weight were higher in $\mathrm{CD}$. The duration also had significant effect on sprout length and fresh weight. Generally sprout length and fresh weight increased with increasing time. Both sprout length and fresh weight were the 
highest between 96 and 120 hours after the test. The interactions of CD and DAL on sprout length and sprout fresh weight were significant $(\mathrm{P} \leq 0.05)$ (Table 4). Sprout length was increased by 8 -times between 24 and 120 hours in $\mathrm{CD}$ and the figure was 7.5 -folds in DAL condition. On the other hand sprout fresh weight increased by 4 -folds between 24 and 120 hours in CD and by 4.6 -folds in DAL condition.

Table 4. Combined effect of Light and harvest duration on seed germination and sprout yield parameters in Mung bean

\begin{tabular}{lllllll}
\hline CD) / DAL & $\begin{array}{l}\text { Harvest } \\
\text { duration } \\
\text { (hours) }\end{array}$ & $\begin{array}{l}\text { Sun dry } \\
\text { seed wt./ } \\
\mathbf{1 0} \text {-seeds }(\mathbf{g})\end{array}$ & $\begin{array}{l}\text { Germination } \\
\mathbf{( \% )}\end{array}$ & $\begin{array}{l}\text { Sprout } \\
\text { length }(\mathbf{c m})\end{array}$ & $\begin{array}{l}\text { Sprout fresh } \\
\mathbf{w t} / \mathbf{1 0} \text { - } \\
\text { seedlings(g) }\end{array}$ & $\begin{array}{l}\text { Sprout } \\
\text { dry wt./ } \\
\mathbf{1 0} \text {-seedlings } \\
\text { (g) }\end{array}$ \\
\hline $\mathrm{CD}$ & 24 & $0.63 \mathrm{ab}$ & $100.0 \mathrm{a}$ & $3.31 \mathrm{f}$ & $1.28 \mathrm{ef}$ & $0.46 \mathrm{a}$ \\
& 48 & $0.60 \mathrm{c}$ & $95.0 \mathrm{ab}$ & $6.23 \mathrm{de}$ & $1.97 \mathrm{~d}$ & $0.42 \mathrm{abc}$ \\
& 72 & $0.64 \mathrm{a}$ & $97.5 \mathrm{ab}$ & $15.72 \mathrm{c}$ & $3.97 \mathrm{bc}$ & $0.42 \mathrm{abc}$ \\
& 96 & $0.61 \mathrm{bc}$ & $90.0 \mathrm{~b}$ & $23.06 \mathrm{~b}$ & $4.72 \mathrm{a}$ & $0.38 \mathrm{c}$ \\
& 120 & $0.61 \mathrm{abc}$ & $100.0 \mathrm{a}$ & $26.15 \mathrm{a}$ & $4.98 \mathrm{a}$ & $0.41 \mathrm{bc}$ \\
& 24 & $0.61 \mathrm{bc}$ & $97.5 \mathrm{ab}$ & $2.35 \mathrm{f}$ & $1.03 \mathrm{f}$ & $0.44 \mathrm{ab}$ \\
& 48 & $0.62 \mathrm{abc}$ & $97.5 \mathrm{ab}$ & $4.20 \mathrm{ef}$ & $1.68 \mathrm{de}$ & $0.42 \mathrm{abc}$ \\
& 72 & $0.62 \mathrm{abc}$ & $95.0 \mathrm{ab}$ & $8.00 \mathrm{~d}$ & $3.48 \mathrm{c}$ & $0.39 \mathrm{bc}$ \\
& 96 & $0.627 \mathrm{ab}$ & $97.5 \mathrm{ab}$ & $15.70 \mathrm{c}$ & $4.49 \mathrm{ab}$ & $0.41 \mathrm{bc}$ \\
& 120 & $0.62 \mathrm{abc}$ & $95.0 \mathrm{ab}$ & $17.75 \mathrm{c}$ & $4.77 \mathrm{a}$ & $0.42 \mathrm{abc}$ \\
\hline
\end{tabular}

In a column under a particular variable, figures followed by different letter (s) are significant at $\mathrm{P} \leq 0.05$

CD: Continuous dark, and DAL: Dark alternated Light

\section{Proximate composition of seed and sprout of Lignosus and Mung beans:}

The temperature and light had a significant effect on proximate composition of Lignosus and Mung beans. Irrespective of temperature and light treatments, protein content of bean sprout was much higher than that in the dry seed in both the species (Table 5). In Lignosus bean, protein content of sprout produced under ambient temperature in the continuous dark alternated by $1 / 2 \mathrm{hr}$ light daily (DAL) was higher $(29.97 \%)$ than in the other light and temperature treatments (average of $25.85 \%$ ). Contrary, in Mung bean protein percentage of sprouts under ambient temperature at DAL was lower (29.46\%) 72 hours after setting the test. The highest protein percentage $(33.24 \%$ ) was found in Mung bean sprout at $30^{\circ} \mathrm{C}$ under continuous dark. The highest nitrogen free extract (NFE or total carbohydrate) (65.91\%) was observed in Mung bean seed. In Lignosus, fibre content was higher in sprout than in the dry seed and the trend was reverse in Mung bean. The highest amount of ash $(6.17 \%)$ was found in Lignosus bean sprout under ambient temperature at DAL. Ether extract or crude fat was lower in sprout than the dry seed in both the species.

Vitamin C content: Vitamin C content was much

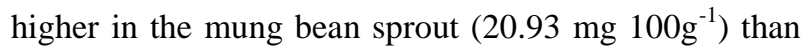

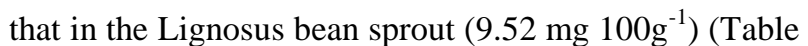
6). No vitamin $C$ was detected in the dry seeds of both the species.

Bean sprouts are widely used as inexpensive, cheaper and protein rich vegetables and salads in Southeast Asia, Japan and other countries. In Bangladesh it is served to the foreigners in five star hotels. In the current study temperatures affected sprout size and weight (Tables 1 and 2). Similar results were also reported by Huang et al. (2006) that increasing temperature also increased sprout length and sprout yield. Duration after soaking the seeds also affected sprout production. The longer and increased sprout weights were observed between 96 and 120 hours in both the species. Results of interaction of temperature and duration showed that better sprout yield was obtained at $25^{\circ} \mathrm{C}$ after 120 hours in Mung bean and $30^{\circ} \mathrm{C}$ after 120 hours in Lignosus bean. In the current experiments, sprouts were longer in the continuous dark (CD) than in the dark alternated by $1 / 2$ hour light daily (DAL). Islam (2010) also observed similar results that a temperature of $25-30^{\circ} \mathrm{C}$ with $96-$ $120 \mathrm{hrs}$ duration was effective for sprouting in Mung and Lignosus beans with improvement of nutrient contents. Sprout yield (fresh weight) was not significantly different between the species and the light conditions, and therefore either CD or DAL was 
observed equally good for both the species. Hundred grams each of Lignosus and Mung bean seeds produced 800 and $200 \mathrm{~g}$, respectively, of edible fresh sprouts, which is partially similar with the findings of Venyet al. (2009) who found 253-279g fresh sprout in Mung bean from $100 \mathrm{~g}$ seeds. This difference in sprout yield might be due to variation in genotype, seed size and sprouting conditions in the two experiments. Pulse grains in general are used as an alternative to animal protein. Considering the nutritive value, sprout had higher protein content than dry seed in both species (Table 5). Our current result agreed with the report of Mankotia and Modgil (2004) in kidney beans and Shah et al.
(2011) in Mung bean that soaking and sprouting increased crude protein content in sprout compared to dry seeds. Sprouts of both the beans contained appreciable Vitamin C compared to their dry seeds, where no vitamin $\mathrm{C}$ was detected and this was an added advantage. Further, there are few summer vegetables in Bangladesh and even the winter vegetables contain very little protein. Sprouting of these beans is easy to prepare at home and can be used as a rich source of protein to alleviate protein deficiency in Bangladesh. There is a good potentiality of introducing bean sprout in the country

Table 5. Comparison of proximate composition between seed and their sprout in Lignosus and Mung beans

\begin{tabular}{|c|c|c|c|c|c|}
\hline \multirow[b]{2}{*}{ Seed /Sprout } & \multicolumn{5}{|c|}{ Proximate composition (\%) } \\
\hline & $\begin{array}{c}\text { Crude } \\
\text { protein }\end{array}$ & $\begin{array}{l}\text { Crude } \\
\text { fibre }\end{array}$ & $\begin{array}{c}\text { Ether } \\
\text { extract }\end{array}$ & $\begin{array}{c}\text { Nitrogen } \\
\text { free extract }\end{array}$ & Ash \\
\hline \multicolumn{6}{|l|}{ Dry seed } \\
\hline Lignosus bean & $24.46 \mathrm{~d}$ & $5.40 \mathrm{a}$ & $2.23 \mathrm{ab}$ & $62.92 \mathrm{c}$ & $4.99 \mathrm{~b}$ \\
\hline Mung bean & $24.25 \mathrm{~d}$ & $2.25 \mathrm{c}$ & $2.83 \mathrm{a}$ & $65.91 \mathrm{a}$ & $4.76 \mathrm{~b}$ \\
\hline \multicolumn{6}{|l|}{ Sprout } \\
\hline $\begin{array}{l}\mathrm{LBS}^{+} \text {at ambient temp. at } \\
\mathrm{CD}^{*}\end{array}$ & $26.20 \mathrm{c}$ & $2.67 \mathrm{c}$ & $1.29 \mathrm{~b}$ & $64.64 \mathrm{~b}$ & $5.20 \mathrm{a}$ \\
\hline $\mathrm{LBS}$ at $30^{\circ} \mathrm{C}$ at $\mathrm{CD}$ & $25.50 \mathrm{c}$ & $4.09 \mathrm{~b}$ & $1.35 \mathrm{~b}$ & $64.27 \mathrm{~b}$ & $4.79 \mathrm{~b}$ \\
\hline $\begin{array}{l}\mathrm{MBS}^{++} \text {at ambient temp. } \\
\text { at } \mathrm{CD}\end{array}$ & $31.67 \mathrm{~b}$ & $3.79 \mathrm{~b}$ & $1.63 \mathrm{~b}$ & $57.66 \mathrm{~d}$ & $5.25 \mathrm{a}$ \\
\hline $\mathrm{MBS}$ at $25^{\circ} \mathrm{C}$ at $\mathrm{CD}$ & $33.24 \mathrm{a}$ & $5.67 \mathrm{a}$ & $1.45 \mathrm{~b}$ & $54.88 \mathrm{e}$ & $4.76 \mathrm{~b}$ \\
\hline
\end{tabular}

+: LBS: Lignosus bean sprout at 120 hours; ${ }^{++}$: MBS: Mung bean sprout at 72 hours,

*: CD: Continuous dark; In a column, figures with uncommon letter (s) are significantly different at $\mathrm{P} \leq 0.05$ by DMRT.

Table 6. Vitamin $\mathrm{C}$ content of sprout of Lignosus and Mung beans

\begin{tabular}{|c|c|}
\hline Species & $\begin{array}{l}\text { Vitamin } C \text { content } \\
\quad\left(\mathrm{mg} 100 \mathrm{~g}^{-1}\right)\end{array}$ \\
\hline $\begin{array}{l}\text { Lignosus Bean sprout } \\
\text { (5-day old seedling) }\end{array}$ & $9.52 \mathrm{~b}$ \\
\hline $\begin{array}{l}\text { Mung Bean (3-day old } \\
\text { seedling) }\end{array}$ & $20.93 \mathrm{a}$ \\
\hline
\end{tabular}

In a column, figures with uncommon letter (s) are significantly different at $\mathrm{P} \leq 0.05$ by DMRT.

Acknowledgements: The authors gratefully acknowledge the head of the Department of Horticulture for providing germination cabinet, head and technicians of the Department of Animal Nutrition for proximate analyses. The authors also thank Shyla Sharmin for helping in Vitamin $\mathrm{C}$ determination in the Department of Biochemistry and Molecular Biology, Bangladesh Agricultural University, Mymensingh, Bangladesh

\section{References}

Abbas, T. and Mushara, N.A. 2008. The effect of germination of low tannin sorghum grains on its nutrient contents and broiler chick's performance, Pakistan J. Nutr., 7(3): 470-474.

AOAC (Assoc. Official Agric Chemists), 2005. $18^{\text {th }}$ edAssoc. Washington, D.C.

Agustin, J., Klein, B.P., Becker, D., Venugopal, P.B. 1985: Methods of Vitamin Assay ( $4^{\text {th }}$ edn.), Association of Vitamin Chemists. Interscience publisher, USA.

Balasaraswathi, R and Sadasivum, S. 1997. Changes in oil, sugars and nitrogenous compound during germination of sunflower seeds, Helianthus annuus. Plant Foods Hum.Nutr., 51: 71-77.

Chen, S. Breene, W.M.and Schowalter, C. 1987. Effects of growth regulators on yield and quality of mungbean sprouts grown in an automatically controlled chamber. J. Food Quality, 10(4): 219-238.

Chen, Yi-Ping, He, Jun-Min and Li, Ran. 2012. Effects of magnetic fields pretreatment of mung bean seeds on sprout yield and quality. Afr. J. Biotechnol., 11(360: 8932-37.

Giami, S.Y. 1993. Effect of processing on the proximate composition and functional properties of cowpea 
(Vigna unguiculata) flour. Food Chem., 47:153158.

Gomez, K.A. and Gomez, A.A. 1984. Statistical procedures for agricultural research.2nd ed. Int. Rice Res. Inst. John Willey \& Sons, Singapore. p. 207-215.

Huang, W.Z., Hsiao, A.I. and Jordan, L. 2006. Effects of temperature, light and certain growth regulating substances on sprouting, rooting and growth of single-node rhizome and shoot segments of Paspalum distichum L. Weed Res., 27(1): 57-67.

Hussain, I. and Uddin, M.B. 2012. Optimisation effect of germination on functional properties of wheat flour by response surface methodology. Int. Res. Plant Sci., 3(3): 31-37.

Islam, M. J. 2010. Effect of light and temperature on sprout of Mungbean (Vigna radiate Wilczk) and Lignosus (Dipogon lignosus (L.) Verdc) bean. M.S Thesis, Dept. Crop Botany, Bangladesh, Bangladesh Agric. Univ., Mymensingh, Bangladesh.

Kaur, M. and Kawarta, B.L. 2002.Effect of domesting processing on zinc bioavaiability from ricebean (Vigna umbellata) diets. Plant Foods Hum. Nutr., 57: 307-318.

Khattak, A.B., Zeb, A., Khan, M., Bibi, N., Ihsanullah, I. and Khattak, M.S. 2007. Influence of germination techniques on sprout yield, biosynthesis of ascorbic acid and cooking ability in chickpea (Cicer arietinum L.). Food Chem., 103: 115-120.

Lintschinger, J., Fuchs, N., Moser, H., Jager, R., HIebeina, T., Markolin, G. and Gossler, W. 1997. Uptake of various trace elements during germination of wheat, buckwheat and quinoa. Plant Foods Human Nutr., 50: 223-237.

Mankotia, K. and Modgil, R. 2004. Nutritional and physiochemical quality changes in soaked, sprouted and cooked kidney beans. Legume Res., 27(4): 282-285.

Mao, J.J., Dong, J.F. and Zhu, M.Y. 2005. Effect of germination conditions on ascorbic acid level and yield of soybean sprout. J. Sci. Food Agric., 85: 943-947.

Meyerowitz, S. 2012. Health benefits of sprouts. http://www.sproutnet.com/Nutrition-of-Sprouts (accessed on 22 March, 2009).

Rashid, M.M. 1999. 'ShabjiBigghan'(Vegetable Science), Rashid Pub. House.Old DOHS, Dhaka.p.28.

Syed, A.S., Zeb, A., Masood, T., Noreen, N., Abbas, S.J., Samiullah, M., Alim, M.A. and Muhammad, A. 2011. Effects of sprouting time on biochemical and nutritional qualities of Mungbean varieties. Afr. J. Agric. Res., 6(22):5091-98.

Suarni, S. and Rauf, P. 2010. Potency of mung bean sprout as enzyme source ( $\alpha$-amilase), Indonesian $\mathrm{J}$. Chemist.,7(3): 332-336.

Veny, U., Kiran, B. and Bains T.S. 2009. Assessment of suitability of mungbean, chickpea and cowpea cultivars for edible sprouts. J. Food Legumes, 22(4): 288-290.

Yang, F., Basu, T.K. and Ooraikul, B. 2001. Studies on germination conditions and antioxidant contents of wheat grain. Int. J. Food Sci. Nutr., 52(4): 319-330.

Zanabria, E.R., Katarzyna, De Jong, L.E.Q., Birgit, H.B.E. and Robert, M.J.N. 2006. Effect of food processing of pearl millet (Pennisetum glaucum) IKMP-5 on the level of phenolics, phytate, iron and zinc. J. Sci. Food Agric., 86: 1391-1398. 